in many countries could not be judged. In view of all the factors, the working party recommends that consideration of the question of greater facilities for the attendance of scientists at conferences should be deferred until the report of the Drogheda Committee is available.

\section{SUPPLY AND EDUCATION OF MANAGERS FOR BRITISH INDUSTRY}

A

BOOKLET issued by the British Institute of Management contains the text of speeches delivered at the Second Scottish Conference held at Gleneagles during April 10-12. Among the subjects debated was that of finding the next generation of managers for British industry, and Dr. N. C. Hunt, referring to the figures supplied by Dr. E. Ashby, which indicate that industry will in future have to recruit its managerial staff from the universities because the reservoir of highly intelligent young people available outside the universities is drying up, discussed the kind of education and training which should be given to university students.

In his paper Dr. Hunt pointed out that, of hundreds of departments of business administration in the United States, only thirty are recognized by the Association of American Universities, and even if it does not matter what subjects are studied in developing the qualities desirable for administration, all subjects are not of equal value in giving the knowledge required. So long as normal university standards of teaching and research are maintained, Dr. Hunt thinks administrative studies could reasonably be included in a university curriculum. Postgraduate training might be given immediately after graduation or after some years of industrial experience; while the short courses offered at the Administrative Staff College, Henley-on-Thames, are extremely useful, they are not the whole answer, especially for the more junior executive who lacks the experience to profit from a course deriving its value from the interchange of experience rather than from formal study. There are already postgraduate courses in business administration at the Universities of London and Manchester and one is under consideration at Edinburgh, while there is a Department of Engineering Production at Birmingham. Dr. Hunt maintained that only in a university could be found the departments specializing in the basic disciplines out of which administration springs-economics, psychology, sociology, law and the applied sciences-and it is upon these that an advanced school of administration must be built.

In emphasizing that education for management must be a co-operative effort between the teaching institutions and industry, Dr. D. S. Anderson pointed out that in practice this means that industry must be willing to lend staff for lecturing in management courses ; to accept trainees for long or short periods ; and to take the trouble to arrange proper schemes of training as well as to supply frank particulars of successful and unsuccessful experiments and to second staff from time to time for further training. It also involves willingness on the part of academic staff to keep up to date by maintaining close contacts with industry, or even to return to industry for periods of 'refreshment', and that industry should be prepared to put some consulting work in the way of academic institutions because of the value which such work has in keeping a teaching staff in touch with actual practice. The content of courses does not present any serious problem; but it is essential that the various kinds of courses should not be limited to managers or potential managers, but should also provide for the training of workers' representatives. Dr. Anderson continued by saying that intelligent discussion -for example, in joint consultation-means intelligence on both sides of the table, and he thinks that only by education and training could one remove the feeling of inferiority to which lack of co-operation is so often due.

\section{SUSCEPTIBILITY OF THE GUINEA PIG TO PHARMACOLOGICAL FACTORS FROM ITS OWN SERUM}

\author{
By Drs. M. E. MACKAY*, A. A. MILES, C.B.E., \\ M. SCHACHTER and D. L. WILHELM
}

Lister Institute of Preventive Medicine, London, S.W.I

$\mathrm{D}^{\mathrm{T}}$ URING a search in the guinea pig for endogenous substances responsible for the vascular and toxic phenomena of inflammation, we discovered in the blood serum of that animal a number of striking pharmacological activities, apparently due to substances of high molecular weight. Serum and serum. fractions proved to contain substances increasing the permeability of skin capillaries (permeability factors; PF), lowering the blood pressure (hypotensive factor; HF), and decreasing the smooth muscle contractor action of histamine (anti-histamine factors; AHF). None of these substances is demonstrable in fresh undiluted serum, but two are activated when the serum is diluted in 0.85 per cent saline: a permeability factor, $\mathrm{PF} / \mathrm{Dil}$; and an antihistamine factor, AHF/Dil. A second permeability factor accumulates in undiluted serum which has been held for several days at $2^{\circ} \mathrm{C}$.; that is, on ageing of the serum. This we designate PF/Age.

$P F / D i l$. When $0 \cdot 1-\mathrm{ml}$. volumes of serial dilutions of fresh serum are injected intracutaneously into depilated albino guinea pigs with pontamine blue in their circulation ${ }^{1}$, within three minutes capillary permeability is substantially increased and the dye exudes into the injection site to form a circular blue lesion. Serum is activated only when it is diluted beyond 1/15-1/30. Maximum activation, as indicated by maximum average diameter of lesion, occurs at $1 / 100-1 / 400$, and the activity is diluted out at about $1 / 5,000$ (Fig. 1). The dilution effect is evident even in the animal from which the serum is obtained. The activation is to some extent reversible, because when diluted serum is reconcentrated at $2^{\circ} \mathrm{C}$. by filtration of the saline through cellophan, it partly regains its inactivity. Unlike substances such as histamine or the histamine-liberator $48 / 80^{1}$, the factor is not antagonized by mepyramine given in intra-peritoneal doses of $20 \mathrm{mgm}$. $/ \mathrm{kgm}$. body-weight two hours before the test. It is relatively heat-labile, a 2 per cent solution of serum being largely inactivated by heating for $1 \mathrm{~min}$. at $100^{\circ} \mathrm{C}$.

\footnotetext{
* Working on behalf of the Medical Research Council.
} 